\title{
FACTORS AFFECTING LABOR PRODUCTIVITY: AN EMPIRICAL EVIDENCE FROM PAKISTAN
}

\author{
Ghulam Sarwar a, ${ }^{\text {, }}$, Muhammad Fayyaz Sheikh ${ }^{\text {b, Iqra Rabnawaz }}{ }^{\mathrm{c}}$ \\ ${ }^{a}$ Noon Business School, University of Sargodha, Sargodha, Pakistan \\ ${ }^{b}$ Lyallpur Business School, Government College University Faisalabad, Pakistan \\ c School Education Department, Sargodha, Government of Punjab, Pakistan
}

\section{ARTICLE INFO}

\section{Article history}

Received: October 04, 2021

Revised: December 22, 2021

Accepted: December 25, 2021

\section{Keywords}

Labor productivity

Wage rate

Human capital investment

Inflation rate

\section{ABSTRACT}

Labor productivity is important as it is the major factor determining nations' living standards. This study analyzes the factors affecting labor productivity in Pakistan using time series data. ARDL model is applied for estimation of the long run relationship of variables for the period 1981-2018. Data have been taken from the Handbook of Statistics of State Bank of Pakistan and various economic surveys of Pakistan. The findings show that wages, human capital investment, labor force participation, and inflation significantly affect labor productivity. The results indicate that wage rate has a positive effect on labor productivity, and human capital investment also is positively related to labor productivity. At the same time, labor force participation and inflation are negatively related to labor productivity. These findings imply that labor productivity can be raised by increasing the wage rate and investing more in human capital. Results are consistent with efficiency wage theory and human capital theory.

\section{*Email: sarwar.maqbool@uos.edu.pk} https://doi.org/10.52223/jei3032112

(C) The Author(s) 2021.

This is an open access article under the CC BY license (http://creativecommons.org/licenses/by/4.0/).

\section{INTRODUCTION}

Labor productivity has become a dominant factor that not only affects the competitiveness of the industry but also affects profitability of firms due to increasing competition in international markets. Productivity can be formalized as the capability of the firms to produce goods and services with a given level of inputs which include land, labor, capital, etc. (Patra $\&$ Nayak, 2012). It is very important to improve the efficiency of factor of production in order to increase the economic growth of a country. Higher productivity leads to low per unit cost, produce higher quality product and higher capability of the firms to compete in the international market, and growth in the export of the country (Papadogonas \& Voulgaris, 2005). Though there are different aspects of productivity which include labor productivity, capital productivity and total factor productivity, but labor productivity is very important because labor is a dominant and active factor used in production process.

The importance of labor productivity is best elaborated by the Nobel Laureate Paul Krugman “Productivity isn't everything, but in the long run it is almost everything. A country's ability to improve its standard of living over time depends almost entirely on its ability to raise output per worker". Labor productivity is an influential factor in the competitiveness for both national economies and individual enterprises. Due to rising competition, labor productivity has become influential factor which affect the profitability of firm in domestic market as well as in international markets. Higher productivity not only indicated the availability of cheaper amount of goods and services in the economy which is beneficial for domestic consumer but also encourage the foreign investor to setup their business in the country due to low per unit cost and higher profit. Expansion of labor productivity is essential for, raising quality of life and improvement of workers' welfare since raising labor productivity can lead to higher wages and more investment in human resources (Heshmati \& Rashidghalam, 2018).

Due to rapid globalization, unprecedented development occurs in the field of information and technology since the 1980s. Several developing countries which include China and India get benefits from these modern developments and gain high economic growth. Unfortunately, Pakistan has failed to take advantage from these advancements. Average economic growth rate during decade of 1980 s was $6.5 \%$. Whereas, it remained relatively low in last three decades between 4-5\%. Labor productivity, grow at $4.2 \%$ per annum in $1980 \mathrm{~s}$. Whereas, during 1990s, it decreased to $1.8 \%$ and continuously dropped to $1.3 \%$ during 2000-2015. More importantly, its growth rate was just 1\% during 2007-2015. Labor productivity grew at $2.3 \%$ per annum 1980-2015 (Amjad \& Awais, 2016).

Dua and Garg (2019) studied determinants of labor productivity in countries of the Asia-Pacific region using panel 
data for the period 1980-2014. The study suggests that foreign direct investment and trade openness have a significant positive effect on developing countries while trade openness only affects productivity of developed countries of Asia-Pacific. Moreover, the share of agriculture in GDP affects significantly productivity in developing countries only, and capital deepening has a lower effect for developed countries than developing ones. Samargandi (2018) analyzed determinants of labor productivity of MENA countries using panel data over the period 1980-2014. The study found that human capital, financial development, trade openness and capital stock are positively related to labor productivity. Whereas, compensation is negatively related to labor productivity. Asghar et al. (2017) tried to study the role of human capital in labor productivity in district Lahore. Cross sectional data has been used and data was collected from manufacturing, labor of trading and services sector. The study indicated that education had a positive association with labor efficiency. Human capital which includes educational training and skill, increases the labor productivity which ultimately enhance the firm's performance.

Heshmati and Rashidgalan (2018) analyzed the labor productivity in the manufacturing sector of Kenya. They used cross sectional data and revealed that wage rate, education, training and capital intensity were main determinants and positively influenced the labor productivity. A large share of female in labor force led to decrease the labor productivity. Amjad and Awais (2016) focused on the productivity performance of Pakistan from 1980 to 2015. This study tried to explain those factors which reduce the total factor productivity and labor productivity. The results showed that, over these 35 years, the contribution of physical capital and education remains modest and there has been a decreasing trend in TFP growth. Lack of sustainable growth and decreasing trend of investment is the major cause of low contribution of total factor productivity. Islam et al. (2015) investigated the relationship between labor productivity and wage rate in Tanzania and also tried to find out the determinants of wage rate. The study was based on time series data from 1966 to 2010. Results of the study showed that experience, education and location were the key determinants and positively influenced the wage rate. The key finding of the study was that wage rate influenced by other factors rather than workers' productivity in Tanzania. Granger causality test clarified that real wage only granger caused the workers efficiency and positively influenced the productivity of the workers.

Yildirim (2015) tried to estimate the relationship among labor productivity, inflation and wage rate in manufacturing sector of Turkey over the period from 1988 to 2012. There existed a strong relationship between inflation and labor productivity. The study suggests that inflation adversely affected the labor productivity because it decreased the purchasing power of the workers and also affected the firm's investment plans. Inflation had a greater influence on productivity as compared to wage rate. Moreover, there was a weak association between wage rate and labor productivity.

Arshad and Malik (2015) discussed the effects of human capital on labor productivity in Malaysia by using panel data from 2009 to 2012. The study revealed that human capital had a positive and significant influence on labor efficiency. Their finding also revealed that education and health played an important role to enhance the labor productivity in Malaysia. Fleisher et al. (2011) tried to examine the role of education on worker productivity in China using data of firms for the period 1998-2000. Results of the study indicated that the marginal productivity of more educated workers increases by large margin as compared to less educated. Ismail (2009) investigated the influence of human capital on output growth and labor productivity in the manufacturing and service sectors in Malaysia. Results of the study showed that human capital and capital labor ratio had a positive association with output growth and labor productivity.

Given the trends in labor productivity, the objective of this study is to find out the determinants of labor productivity in Pakistan.

\section{METHODOLOGY}

This study explored the determinants of labor productivity in Pakistan. The following empirical model is utilized to investigate the determinants of labor productivity.

$$
L L P=\beta_{1}+\beta_{2} L W G+\beta_{3} L H C+\beta_{4} L I N F+\beta_{5} L F+\mu(1)
$$

All the variables are taken in logarithms form. LLP is log of labor productivity; LWG is log of wages; LHC is log of human capital investment; LINF is log of Inflation; LF is labor force participation.

\section{Variables Description}

Labor Productivity: Labor productivity can be defined as output per worker. In other words, it measures the efficiency of the country that how inputs are used to produce goods and services. Ratio of real GDP to total employment is used as a measure of labor productivity.

Wages: Real minimum wage is used as a proxy for real wages due to the lack of time series data on average real wages. Real wages and labor productivity are closely related to each other. Higher wages motivate the workers to improve their skills and efficiency (Jain, 2019). Number of previous studies showed a positive association between these variables.

Human Capital Investment: Human capital is also a key factor that raises the labor productivity. Human capital theory is based on the assumption that education, training and knowledge increase the marginal physical product of labor. Real government expenditure on education is used as a proxy for human capital investment. A positive relationship between education and labor productivity is expected.

Inflation: GDP-deflator is used as a proxy for inflation because it measures the prices of all goods and services produced by labor in the country. A negative relationship is expected between inflation and labor productivity.

Labor Force Participation: Labor force participation is measured as the ratio of numbers of the employed labor force to total population. Negative relationship is expected between labor force participation and labor productivity.

Macro level annual time series data is used from 1981 to 2018 for estimation of the empirical model. Data have been taken from the Handbook of Statistics of State Bank of Pakistan and various economic surveys of Pakistan. This study first tests the 
stationarity of all variables using Augmented Dickey and Fuller (1981) and Phillip and Perron (1988) tests. After testing the stationarity, Autoregressive Distributed Lag Model (ARDL hereafter) model is used for empirical model estimation.

ARDL approach (Pesaran et al., 2001) is a standard least square method that consists of lag terms of dependent and independent variables. ARDL model can be used whether underlying variables are integrated on level i.e. I(0) or integrated of order one i.e. I(1) or a combination of both but neither of variable should be integrated of order two i.e. I(2). This technique can also be used for small sample size which give unbiased and efficient results. ARDL is employed in three steps.

Step 1: The ARDL-ECM model for bound testing is written as follow;

$\Delta L L P=\propto_{0}+\sum_{i=1}^{n} \beta_{1 i} \Delta L L P_{t-1}+\sum_{i=0}^{n} \beta_{2 i} \Delta L W G_{t-1}+$ $\sum_{i=0}^{n} \beta_{3 i} \Delta L H C_{t-1}+\sum_{i=0}^{n} \beta_{4 i} \Delta L I N F_{t-1}+\sum_{i=0}^{n} \beta_{5 i} \Delta L F_{t-1}+$ $\beta_{6} L L P_{t-1}+\beta_{7} L W G_{t-1}+\beta_{8} L H C_{t-1}+\beta_{9} L I N F_{t-1}+\beta_{10} L F_{t-1}+$ $\varepsilon_{t}$

Where $\Delta$ is difference operators while $\varepsilon_{t}$ is white noise error term. In presence of long run relationship between variables, i.e., cointegration, following ARDL model is estimated.

$L L P=\alpha_{0}+\sum_{i=1}^{n} \beta_{1} L L P_{t-1}+\sum_{i=0}^{n} \beta_{2} L W G_{t-1}+$

$\sum_{i=0}^{n} \beta_{3} L H C_{t-1}+\sum_{i=0}^{n} \beta_{4} I N F_{t-1}+\sum_{i=0}^{n} \beta_{5} L F_{t-1}+e_{t}$

Whereas, short run relationship is estimated as follows;
$\Delta L L P=\alpha_{0}+\sum_{i=1}^{n} \beta_{1} \Delta L L P_{t-1}+\sum_{i=0}^{n} \beta_{2} \Delta L W G_{t-1}+$ $\sum_{i=0}^{n} \beta_{3} L H C_{t-1}+\sum_{i=0}^{n} \beta_{4} \Delta I N F_{t-1}+\sum_{i=0}^{n} \beta_{5} \Delta L F_{t-1}+$ $\lambda_{1} E C M_{t-1}+u_{t}$

The study also tests for the serial correlation, heterosckedasticity and normality utilizing usual econometric tests.

\section{RESULTS AND DISCUSSION}

\section{Unit Root Tests}

The results of the Augmented Dickey-Fuller (ADF hereafter) test and Phillip-Perron (PP hereafter) tests are presented in Tables 1 and 2, respectively. The stationarity is tested under two models, namely, only intercept and intercept with the trend for the variables of the study. Moreover, numbers in parentheses show number of optimum lags (k) chosen by Schwarz Information Criterion. The estimates of ADF test show that all variables are stationary at the first difference I(1) with both models except inflation which is also stationary at level with only intercept with trend model but stationary at $1^{\text {st }}$ difference with intercept model. The finding of PP test, in Table 2 , verifies that all variables are stationary at first difference with intercept and intercept with trend models. No variable is integrated of order two, i.e., I(2); therefore, ARDL is used for estimation of long run relationship of variables of empirical model of the study.

Table 1. Augmented Dickey Fuller Test.

\begin{tabular}{|c|c|c|c|c|}
\hline \multirow[b]{2}{*}{ Variables } & \multicolumn{2}{|c|}{ At level } & \multicolumn{2}{|c|}{ At 1st difference } \\
\hline & Intercept & Trend \& intercept & Intercept & trend \& intercept \\
\hline$\overline{\mathrm{LLP}}$ & $-2.387(0)$ & $-2.355(0)$ & $-5.592 *(0)$ & $-5.898 *(0)$ \\
\hline LWG & $2.541(3)$ & $-2.386(0)$ & $-6.647 *(0)$ & $-5.380 *(2)$ \\
\hline LHC & $-1.086(0)$ & $-2.842(0)$ & $-4.448 *(0)$ & $-4.496^{*}(0)$ \\
\hline LINF & $0.839(0)$ & $-4.440 *(4)$ & $3.841 *(4)$ & $-3.544(4)$ \\
\hline LF & $-0.957(0)$ & $-1.806(0)$ & $-4.413^{*}(0)$ & $-4.312^{*}(0)$ \\
\hline
\end{tabular}

Table 2. Phillip-Perron Test.

\begin{tabular}{lcccc}
\hline \multirow{2}{*}{ Variables } & \multicolumn{2}{c}{ At level } & \multicolumn{2}{c}{ At 1st difference } \\
\cline { 2 - 4 } & Intercept & Trend \& intercept & Intercept & Trend \& intercept \\
\hline LLP & -3.232 & -2.345 & $-5.592^{*}$ & $-6.026^{*}$ \\
LWG & -2.971 & -2.225 & $-6.647^{*}$ & $-19.468^{*}$ \\
LHC & -1.055 & -3.029 & $-4.375^{*}$ & $-4.444^{*}$ \\
LINF & 0.538 & -2.057 & $3.840^{*}$ & $-3.857^{*}$ \\
LF & -0.957 & -1.931 & $-4.413^{*}$ & $-4.312^{*}$ \\
\hline
\end{tabular}

\section{Autoregressive Distributed Lag Model (ARDL)}

For ARDL analysis, first we choose an appropriate model from the alternatives. An Akaike information criterion (AIC) is used for the selection of optimal lag length for the variables of the model. The model with the lowest AIC value is considered the best. ARDL $(1,0,1,1,1)$ is the best model for this study given the data on variables. Next, bound testing requires to estimate ARDL-ECM equation (4) to check the cointegration among labor productivity, wage rate, human capital investment, inflation and labor force participation. F-statistic for bound testing is presented in Table 3. The results of bound test of cointegration show the existence of cointegration among the variables because the F-Statistic value 5.66 is greater than the upper bound critical value. It neither exists below the lower bound (no cointegration) nor lies between the upper and lower bound (inconclusive zone). 
Table 3. Bound Testing Cointegration.

\begin{tabular}{|c|c|c|c|c|}
\hline \multirow[t]{2}{*}{ F-Statistics Value } & \multirow[t]{2}{*}{ K } & \multirow[t]{2}{*}{ Significant level } & \multicolumn{2}{|c|}{$\begin{array}{l}\text { Bound Critical Values } \\
\text { Intercept and no trend }\end{array}$} \\
\hline & & & $\mathrm{I}(0)$ & $\mathrm{I}(1)$ \\
\hline \multirow{3}{*}{5.66} & \multirow{3}{*}{4} & $10 \%$ & 2.43 & 3.57 \\
\hline & & $5 \%$ & 2.85 & 4.01 \\
\hline & & $1 \%$ & 3.83 & 5.12 \\
\hline
\end{tabular}

After finding the cointegration, the ARDL approach estimates the long run relationship. The results of long run coefficients are shown in Table 4. The coefficient of wages is positive and statistically significant, which indicates that one percent increase in wage rate leads to $0.06 \%$ rise in labor productivity. It verifies the "Efficiency wage theory" which suggested that higher wages influence labor productivity. When firms want to raise the productivity of labor, they offer higher wages than market clearing wage. Other reason to offer higher wages is to minimize the labor turnover, so that firms can retain skilled and experience employees than hiring newly and unskilled employees. This finding is consistent with the findings of Jain (2019), Dritsaki (2016), Tang (2014), Kumar et al. (2012), Narayan and Smyth (2009), and Yusof (2008).

Table 4. Estimated Long Run Coefficients.

\begin{tabular}{|c|c|c|c|}
\hline Variables & Coefficient & Standard Error & t-statistics \\
\hline LWG & 0.068836 & 0.026243 & 2.622997 \\
\hline LHC & 0.190252 & 0.028514 & 6.672265 \\
\hline LINF & -0.194216 & 0.053681 & -3.617974 \\
\hline LF & -1.029194 & 0.233913 & -4.399907 \\
\hline C & 4.749511 & 0.050193 & 94.62432 \\
\hline
\end{tabular}

Human capital investment shows a positive relationship with labor productivity. If there is one percent increase in the human capital investment, labor productivity will increase by 0.190 percent. Dua and Garg (2019), Samargandi (2018), Islam et al. (2015), and Aggrey et al. (2010) reported similar results. Inflation rate has a negative impact on labor productivity. Its coefficient represents that one percent increase the inflation rate, reduce the labor productivity by 0.194 percent. Inflation negatively affects labor efficiency because it raises the rental price of capital and firms substitute the labor for capital. Ultimately productivity will decrease due to the entrance of new workers. Dritsaki (2016), Yildirim (2015), Tang (2014), Kim et al. (2013), Kumar at el. (2012) and Papapetrou (2003) have reported similar findings. The result shows the negative and significant impact of labor force participation on labor productivity. It may be due to the surplus labor force in the workforce, especially in the agriculture sector, that decreases the workers' efficiency.

The short run results are presented in Table 5. The coefficients of wages and labor force participation shows statistical significance and signs are also according to economic theory. Whereas the coefficients inflation and human capital investment have a correct sign but are not statistically significant in the short run. The coefficient of ECM $(-1)$ is equal to -0.80 suggesting a high speed of the adjustment back to equilibrium. This indicates that the $80 \%$ deviation from equilibrium is corrected during a year.

Finally, diagnostic tests are applied to check the serial correlation, heteroskedasticity and normality. The estimates of various test statistics are shown the Table 6 .

Table 5. Estimate Error Correction Model.

\begin{tabular}{|c|c|c|c|}
\hline Variable & Coefficient & Standard Error & t-statistic \\
\hline$\overline{\mathrm{D}(\mathrm{LWG})}$ & 0.055113 & 0.020836 & 2.645093 \\
\hline $\mathrm{D}(\mathrm{LHC})$ & 0.041293 & 0.040966 & 1.007976 \\
\hline $\mathrm{D}(\mathrm{LINF})$ & -0.046099 & 0.083231 & -0.553867 \\
\hline $\mathrm{D}(\mathrm{LF})$ & -1.421756 & 0.224677 & -6.327996 \\
\hline $\operatorname{ECM}(-1)$ & -0.800653 & 0.198095 & -4.041768 \\
\hline \multicolumn{2}{|c|}{ Akaike Information Criterion= -7.377} & R-Square $=0.988$ & \\
\hline \multicolumn{2}{|c|}{ Schwarz Criterion $=-6.935$} & Adjusted R-Square $=0.981$ & \\
\hline \multicolumn{2}{|c|}{ Hannan-Quinn Criterion= -7.259} & F-Statistic $=154.83$ & \\
\hline \multicolumn{2}{|c|}{ DW Statistic $=1.99$} & $\operatorname{Prob}(\mathrm{F}$-statistic $)=0.000$ & \\
\hline
\end{tabular}

Breusch-Godfrey Serial Correlation LM Test has been applied to test the serial correlation. The test reports that $p$-value is greater than the significant level 0.05 and we accept the null hypothesis, which means that there is no autocorrelation in the model. White LM test is used to test the null hypothesis of no heteroskedasticity, it indicates the absence of heteroskedasticity in the model. To identify normal distribution of the residuals, Jarque-Bera test is used. It shows that the residuals are normally distributed. 
Table 6: Diagnostic Tests

Breusch-Godfrey Serial Correlation LM Test

Null Hypothesis: There is no Serial Correlation

$\begin{array}{llll}\text { F-Statistic } & 0.028161 & \text { P-Value } & 0.9723 \\ \text { LM-Statistic } & 0.103530 & \text { P-Value } & 0.9496\end{array}$

White's Heteroskedasticity Test:

Null Hypothesis: There is no Heteroskedasticity

$\begin{array}{llll}\text { F-Statistic } & 0.737598 & \text { P-Value } & 0.6587 \\ \text { LM-Statistic } & 0.275767 & \text { P-Value } & 0.5610\end{array}$

Jarque-Bera Normality Test:

Null Hypothesis: Residuals are normally distributed

$\begin{array}{llll}\text { JB- Statistic } & 0.466377 & \text { P-Value } & 0.792004\end{array}$

\section{CONCLUSIONS}

This study explored the determinants of labor productivity in Pakistan. After testing the stationarity of data, the ARDL model is used for estimation. Results of the study indicate that real wage positivity affects labor productivity because a higher wage rate encourages the workers. Human capital investment is also positively related to labor productivity as more educated workers can perform better by adopting the new innovation and technology as compared to uneducated workers. Inflation has a negative effect on labor productivity as it increases the rental price of capital. Moreover, labor force participation negatively affects labor productivity due to the prevalence of unskilled labor force in the production process. The findings have many important policy implications. Most importantly, labor productivity can be increased by raising real wages because higher wages raise labor productivity, reduce worker turnover, attract more skilled and educated labor, and increase the feelings of loyalty among workers. Moreover, the impact of human capital is undesirably low in spite of an improvement in education over the years, suggesting that human capital is still not at the level when it can be a major factor in increasing labor productivity in Pakistan. Therefore, the government should increase the investment in human capital in order to enhance labor productivity.

\section{REFERENCES}

Aggrey, N., Eliab, L., Joseph, S., 2010. Human capital and labor productivity in East African manufacturing firms. Curr. Res. J. Econ. Theory 2, 48-54.

Amjad, R., Awais, N., 2016. Pakistan's Productivity Performance and TFP Trends, 1980-2015: Cause for Real Concern. Lahore J. Econ. 21, 33-63.

Arshad, M.N.M., Malik, A.Z., 2015. Quality of human capital and labor productivity: a case of Malaysia. Int. J. Econ. Manag. Account. 23, 37-55.

Asghar, N., Danish, M.H., Rehman, H., 2017. Human Capital and Labour Productivity A Case Study of District Lahore. JPUHS. 30, 163-179.

Dickey, D.A., Fuller, W.A., 1981. Likelihood Ratio Statistics for Autoregressive Time Series with a Unit Root. Econometrica 49, 1057-1072.

Dritsaki, C., 2016. Real wages, inflation, and labor productivity: Evidences from Bulgaria and Romania. J. Econ. Financ. Stud. 4, 24-36.

Dua, P., Garg, N.K., 2019. Determinants of labour productivity: Comparison between developing and developed countries of Asia-Pacific. Pacific Econ. Rev. 24, 686-704.

Fleisher, B.M., Hu, Y., Li, H., Kim, S., 2011. Economic transition, higher education and worker productivity in China. J. Dev. Econ. 94, 86-94.

Heshmati, A., Rashidghalam, M., 2018. Labour productivity in Kenyan manufacturing and service industries, in: Determinants of Economic Growth in Africa. Springer, pp. 259-286.

Islam, R., Kinyondo, A., Nganga, J., 2015. Real wages and labour productivity in Tanzania: How do they link? J. African Stud. Dev. 7, 81-98.

Ismail, R., 2009. The impact of human capital attainment on output and labor productivity of Malay firms. J. Int. Manag. Stud. 4, 221-230.

Jain, H., 2019. Wage-productivity relationship in Indian manufacturing industries: Evidences from statelevel panel data. Margin J. Appl. Econ. Res. 13, 277305.

Kim, S., Lim, H., Park, D., 2013. Does productivity growth lower inflation in Korea? Appl. Econ. 45, 2183-2190.

Kumar, S., Webber, D.J., Perry, G., 2012. Real wages, inflation and labour productivity in Australia. Appl. Econ. 44, 2945-2954.

Narayan, P., Smyth, R., 2009. The effect of inflation and real wages on productivity: new evidence from a panel of G7 countries. Appl. Econ. 41, 1285-1291.

Papadogonas, T., Voulgaris, F., 2005. Labor productivity growth in Greek manufacturing firms. Oper. Res. 5, 459472 .

Papapetrou, E., 2003. The Inflation and Productivity Relationship in Poland. J. Econ. Bus. 2003, 11-33.

Patra, S., Nayak, S.R., 2012. A theoretical study on the relationship between wages and labor productivity in industries. Int. J. Econ. Res. 3, 157-163.

Pesaran, M.H., Shin, Y., Smith, R.J., 2001. Bounds testing approaches to the analysis of level relationships. J. Appl. Econom. 16, 289-326.

Phillips, P.C.B., Perron, P., 1988. Testing for a unit root in time series regression. Biometrika 75, 335-346.

Samargandi, N., 2018. Determinants of labor productivity in MENA countries. Emerg. Mark. Financ. Trade 54, 10631081.

Tang, C.F., 2014. The effect of real wages and inflation on labour productivity in Malaysia. Int. Rev. Appl. Econ. 28, 311-322. 
Yildirim, Z., 2015. Relationships among labour productivity, real wages and inflation in Turkey. Econ. Res. Istraživanja 28, 85-103.
Yusof, S.A., 2008. The long-run and dynamic behaviors of wages, productivity and employment in Malaysia. J. Econ. Stud. 35, 249-262.

Publisher's note: Science Impact Publishers remain neutral with regard to jurisdictional claims in published maps and institutional affiliations.

Open Access This article is licensed under a Creative Commons Attribution 4.0 International License, which permits use, sharing, adaptation, distribution and reproduction in any medium or format, as long as you give appropriate credit to the original author(s) and the source, provide a link to the Creative Commons license and indicate if changes were made. The images or other third-party material in this article are included in the article's Creative Commons license, unless indicated otherwise in a credit line to the material. If material is not included in the article's Creative Commons license and your intended use is not permitted by statutory regulation or exceeds the permitted use, you will need to obtain permission directly from the copyright holder. To view a copy of this license, visit https://creativecommons.org/licenses/by/4.0/. 